\title{
Patterns of mortality among migrants to England and Wales from the Indian subcontinent
}

\author{
R BALARAJAN, L BULUSU, A M ADELSTEIN, V SHUKLA
}

\begin{abstract}
Causes of deaths in immigrants to England and Wales from the Indian subcontinent were assessed by ethnic subgroup. Observed and expected deaths for 1975-7 were aggregated to calculate proportional mortality ratios. Observed mortality due to infective and parasitic diseases, endocrine diseases (notably diabetes), diseases of the circulatory system (notably ischaemic heart disease and cerebrovascular disease, in males), and diseases of the digestive system (notably cirrhosis of the liver) exceeded expected mortality. Fewer than expected deaths were due to malignant neoplasms (notably lung cancer and chronic bronchitis); proportional mortality ratios for cancer were lower for Hindu groups than for Moslems and were lowest for Punjabis. Mortality due to ischaemic heart disease, high in all groups, was highest in Moslems. Significantly more Punjabi males died from cerebrovascular disease and cirrhosis of the liver. Diabetes was commonest among Gujaratis.

The variation seen in the patterns of mortality in the different ethnic groups indicates the need for further epidemiological and health service research centred on these communities.
\end{abstract}

\section{Introduction}

Research into disease patterns in immigrants contributes to the understanding of the aetiology of diseases and to meeting needs for health services. Studies on immigrants of Indian descent in various different countries have been published. Incidence of ischaemic heart disease has been shown to be higher among people of Indian descent in England and Wales, ${ }^{1}$ South Africa, ${ }^{2}$ and Fiji. ${ }^{3}$ Lower mortality due to cancer ${ }^{4}$ and higher prevalence of diabetes ${ }^{5}$ have also been shown in these communities in England and Wales. Deaths in England and Wales by place of birth have been analysed for 1970-8 by the Office of Population Censuses and Surveys. ${ }^{6}$ In this study we have analysed the causes of death in immigrants from the Indian subcontinent by their area of origin in the subcontinent.

Medical Department, South West Thames Regional Health Authority and St George's Hospital Medical School, London

R BALARAJAN, MFCM, regional specialist in community medicine and honorary senior lecturer

Medical Statistics Division, Office of Population Censuses and Surveys, London WC2B 6JP

L BULUSU, MA, statistician

Department of Epidemiology and Medical Statistics, London School of Hygiene and Tropical Medicine, London WC1

A M ADELSTEIN, MD

Department of Community Medicine, Faculty of Medicine, University of Southampton, Southampton General Hospital, Southampton SO9 4XY

V SHUKLA, medical student

Correspondence to: Dr R Balarajan, Medical Department, South West Thames Regional Health Authority, London W2 3QR.

\section{Methods}

A proportional mortality analysis was carried out on the deaths in England and Wales in 1975-7 (death certificates for 1977 were available for analysis for the first half of the year only) of those born in India, Pakistan, or Bangladesh. (Other countries in the Indian subcontinent were not included.) Death certificates for these people were extracted and classified into those of Indian descent and those of English descent by analysis of names. Surnames and forenames were used mostly, but, if these were inadequate, name of spouse and name of informant (when applicable and if related) were also used. Those of Indian descent were further classified, still according to name, into Punjabis, Gujaratis, south Indians, Bengalis, Moslems, and others. This classification was primarily regional except for that of Moslems who, by virtue of their scattered distribution and cultural differences, were identified separately as a group for the whole subcontinent. Thus Punjabis, Gujaratis, south Indians, and Bengalis were primarily Hindus but Punjabis also included Sikhs and Gujaratis many Jains. Anglo-Indians and Indians with English names (mostly Christians) were probably often classified as being of English descent because their names were not distinguishable. This was, however, thought to be acceptable for this study, as they probably have a lifestyle similar to that of people of English descent.

As population figures were not available for the ethnic groups that we classified a proportional analysis was carried out age standardising for each sex separately using the age and sex specific proportional rates (five year age groups) of the different causes in each respective year in England and Wales as standard. Observed and expected deaths were aggregated for the entire period to calculate proportional mortality ratios. A proportional mortality ratio of 100 therefore meant that the average mortality for the group, for that cause, as a proportion of total mortality was equal to that for England and Wales after adjustment for differences in the age distribution. Significance indicated was at the $5 \%$ level.

\section{Results}

Altogether 3657 immigrants from the Indian subcontinent of Indian descent died in England and Wales during the study. Table I shows their distribution by ethnic subgroup. The overall ratio of men to women who died was 2.5 to one, but the sex ratio was considerably higher (four to one) for Moslems. The high proportion of male deaths was probably attributable to a younger age distribution as well as to a predominance of males in this immigrant population.

Table II shows proportional mortality ratios and numbers of deaths for particular groups of diseases as defined by International Classification of Diseases (ICD) codes. $^{7}$ More Indians than expected died of parasitic and infective diseases, and mortality due to endocrine, nutritional, and metabolic diseases was increased twofold in people

TABLE I-Number of deaths by age in years, and ethnic group

\begin{tabular}{|c|c|c|c|c|c|c|c|}
\hline \multirow{2}{*}{$\begin{array}{l}\text { Ethnic } \\
\text { group }\end{array}$} & \multirow[b]{2}{*}{ Sex } & \multicolumn{5}{|c|}{ No dying aged: } & \multirow[b]{2}{*}{ Total } \\
\hline & & $0-14$ & $15-44$ & $45-64$ & $65-74$ & $\geqslant 75$ & \\
\hline Punjabis & $\left\{\begin{array}{l}\mathbf{M} \\
\mathbf{F}\end{array}\right.$ & $\begin{array}{l}8 \\
4\end{array}$ & $\begin{array}{r}166 \\
92\end{array}$ & $\begin{array}{l}425 \\
166\end{array}$ & $\begin{array}{r}208 \\
68\end{array}$ & $\begin{array}{l}65 \\
56\end{array}$ & $\begin{array}{l}872 \\
386\end{array}$ \\
\hline Gujaratis & $\left\{\begin{array}{l}\mathbf{M} \\
\mathbf{F}\end{array}\right.$ & $\begin{array}{l}4 \\
4\end{array}$ & $\begin{array}{l}73 \\
66\end{array}$ & $\begin{array}{l}285 \\
139\end{array}$ & $\begin{array}{r}114 \\
65\end{array}$ & $\begin{array}{l}46 \\
51\end{array}$ & $\begin{array}{l}522 \\
325\end{array}$ \\
\hline Moslems & $\left\{\begin{array}{l}\mathrm{M} \\
\mathrm{F}\end{array}\right.$ & $\begin{array}{l}30 \\
13\end{array}$ & $\begin{array}{r}261 \\
91\end{array}$ & $\begin{array}{r}572 \\
99\end{array}$ & $\begin{array}{r}162 \\
48\end{array}$ & $\begin{array}{l}41 \\
23\end{array}$ & $\begin{array}{r}1066 \\
274\end{array}$ \\
\hline Southerners \{ & $\left\{\begin{array}{l}\mathbf{M} \\
\mathbf{F}\end{array}\right.$ & & $\begin{array}{r}16 \\
7\end{array}$ & $\begin{array}{r}38 \\
7\end{array}$ & $\begin{array}{l}7 \\
4\end{array}$ & $\begin{array}{r}10 \\
1\end{array}$ & $\begin{array}{l}71 \\
19\end{array}$ \\
\hline Bengalis & $\left\{\begin{array}{l}\mathbf{M} \\
\mathbf{F}\end{array}\right.$ & 1 & $\begin{array}{r}15 \\
5\end{array}$ & $\begin{array}{r}17 \\
3\end{array}$ & $\begin{array}{l}9 \\
3\end{array}$ & $\begin{array}{l}5 \\
2\end{array}$ & $\begin{array}{l}47 \\
13\end{array}$ \\
\hline Others & $\left\{\begin{array}{l}\mathbf{M} \\
\mathbf{F}\end{array}\right.$ & 1 & $\begin{array}{l}3 \\
2\end{array}$ & $\begin{array}{r}22 \\
2\end{array}$ & $\begin{array}{r}15 \\
3\end{array}$ & $\begin{array}{r}4 \\
10\end{array}$ & $\begin{array}{l}45 \\
17\end{array}$ \\
\hline Total & $\left\{\begin{array}{l}\mathbf{M} \\
\mathbf{F}\end{array}\right.$ & $\begin{array}{l}44 \\
21\end{array}$ & $\begin{array}{l}534 \\
263\end{array}$ & $\begin{array}{r}1359 \\
416\end{array}$ & $\begin{array}{l}515 \\
191\end{array}$ & $\begin{array}{l}171 \\
143\end{array}$ & $\begin{array}{l}2623 \\
1034\end{array}$ \\
\hline
\end{tabular}


born in the Indian subcontinent, with diabetes mellitus accounting for most of this excess (table III). Mortality due to diseases of the digestive system was significantly high $(p<0.05)$ in Indian men overall. Diseases of the upper gastrointestinal tract (ICD codes 530-537), though showing no excess in males, showed a non-significant excess in females overall and a significant excess (proportional mortality ratio 720 ) in Moslem women alone. There was an excess of deaths in Indians of both sexes due to diseases of the genitourinary system, diseases of the blood or blood forming organs, and circulatory diseases. The highest proportional mortality ratio for ischaemic heart disease (171) was seen in Bengalis (22 deaths).

Proportionately fewer deaths due to neoplasms occurred in immigrants born in the Indian subcontinent. Table IV shows proportional mortality ratios for malignant neoplasms of selected sites. Deaths from neoplasms of trachea, bronchus, or lung (ICD code 162) accounted for only $69(24 \%)$ of 282 male deaths and eight $(5 \%)$ of 157 female deaths due to neoplasms in contrast with $39 \%$ and $12 \%$ respectively in England and Wales. Observed mortality due to accidents, poisoning, or violence was more than expected in south Indians and Punjabi males and in females with the exception of Moslems.

\section{Discussion}

This study was based on deaths, occurring in England and Wales in 1975-7, of people born in the Indian subcontinent and with names suggestive of Indian descent. Thus Britons who returned home and Indians indistinguishable by their nonIndian names (Anglo-Indians and possibly some Indian Christians) were excluded. The place of birth of the deceased within the subcontinent was not available. The regional nature of the names was used in all but Moslems as a proxy for the region of origin. We also did not take into account the time spent in the host country.

The method of analysis, based on proportional mortality ratios, had its intrinsic difficulties, which have been discussed elsewhere. ${ }^{8}$ As proportional mortality ratios were based on small numbers, we did not attempt to test specific hypotheses in this study. We have indicated significance of differences between levels in England and Wales in the tables to aid interpretation, but it is to be expected that many relevant high and low proportional mortality ratios would fail to show significance as they are based on small numbers. On the other hand, consistent patterns would indicate a true difference that would have been significant if based on large numbers. Also, a high proportional mortality ratio for one cause can in theory give rise to apparently low values for others, but in fact this effect is likely to be diluted among many other causes.

Ethnic Indians as a group showed a different pattern of mortality from that present in England and Wales. More of them than expected died owing to: infective and parasitic diseases
(ICD codes 000-136), notably tuberculosis; endocrine diseases (ICD codes 240-279), notably diabetes; diseases of the circulatory system (ICD codes 390-458); digestive diseases (ICD codes 520-577); and genitourinary diseases (ICD codes 580-629). Fewer died owing to neoplasms (ICD codes 140-239). This was in general agreement with the findings of the immigrant mortality study based on deaths in 1970-2. ${ }^{\circ}$ Among the more specific causes, mortality due to tuberculosis, diabetes mellitus, and ischaemic heart disease was high in both sexes. Raised mortality for cerebrovascular disease and cirrhosis of the liver was restricted to males only. Cancer of the breast was low among ethnic Indian females as was cancer of the cervix uteri, as reported in east African Indians ${ }^{9}$ and some earlier studies from India ${ }^{10}$ and South Africa. ${ }^{11}$

The extraordinarily high mortality due to tuberculosis was of particular concern as reasonable control is assumed to occur with screening and surveillance of immigrants, especially those from the Indian subcontinent. Examination of immigrants at the time of entry, as practised at present, does not appear to have achieved the intended effect of controlling the incidence of and reducing mortality from tuberculosis. The high incidence of cirrhosis of the liver in ethnic Indians was at variance with the belief that they are fairly abstemious. Though infections could predispose to cirrhosis, the significant findings in the males indicated the need for further studies into drinking habits.

Although strict comparison between cancer registry data from different countries and mortality studies is difficult, it is encouraging that the data for the Bombay Cancer Registry ${ }^{12}$ supported the relative incidences of cancer indicated by the proportional mortality ratios observed by us. For example, the world standardised rate for lung cancer among males in Bombay (1973-5) was estimated as $14 \cdot 2 / 100000 /$ annum in contrast to 79.9 (1973-6) in Birmingham: this was consistent with our finding of a proportional mortality ratio of 18 for Gujaratis living in England and Wales. Similarly, for breast cancer in females the rates were 21.2 and 56.4/100 000/annum for Bombay and Birmingham respectively, consistent with a proportional mortality ratio of 43 for Gujaratis.

Regional variations in disease patterns have been reported from India, ${ }^{13} 14$ and this study also pointed to variations in patterns of diseases at death within ethnic groups living in England and Wales. The length of stay of the deceased in this country and the lifestyles of the different ethnic groups are not sufficiently well known to explain the variations. Punjabis, from the north west of India, are mostly followers of Sikhism. One would expect to find more vegetarians within this ethnic group as Punjabi Moslems are identified along with other Moslems as a separate group. Cirrhosis of the liver, cerebrovascular disease, and mental disorders caused more deaths in Punjabi males, with

TABLE II-Proportional mortality ratios (number of deaths) for classified groups of diseases by ethnic group. (Bengalis and others not listed owing to small numbers)

\begin{tabular}{|c|c|c|c|c|c|c|}
\hline \multirow[b]{2}{*}{ Cause of death (ICD code) } & \multirow[b]{2}{*}{ Sex } & \multicolumn{4}{|c|}{ Ethnic group } & \multirow{2}{*}{ Total } \\
\hline & & Punjabis & Gujaratis & Moslems & Southerners & \\
\hline Infective and parasitic diseases (000-136) & $\left\{\begin{array}{l}\mathrm{M} \\
\mathrm{F}\end{array}\right.$ & $\begin{array}{l}366 *(25) \\
539 *(18)\end{array}$ & $\begin{array}{l}454 *(15) \\
638 *(15)\end{array}$ & $\begin{array}{l}429 *(37) \\
571 *(18)\end{array}$ & $\begin{array}{r}212(1) \\
1053^{*}(2)\end{array}$ & $\begin{array}{l}397^{*}(79) \\
577^{*}(53)\end{array}$ \\
\hline Neoplasms (140-239) & $\left\{\begin{array}{l}\mathbf{M} \\
\mathbf{F}\end{array}\right.$ & $\begin{array}{l}32 *(66) \\
42 *(52)\end{array}$ & $\begin{array}{l}46^{*}(58) \\
44^{*}(46)\end{array}$ & $\begin{array}{l}53 *(138) \\
61 *(53)\end{array}$ & $\begin{array}{l}38^{*}(6) \\
63(4)\end{array}$ & $\begin{array}{l}45^{*}(282) \\
48^{*}(157)\end{array}$ \\
\hline Endocrine, nutritional, and metabolic disease $(240-279)$ & $\left\{\begin{array}{l}\mathbf{M} \\
\mathbf{F}\end{array}\right.$ & $\begin{array}{l}254^{*}(22) \\
173(10)\end{array}$ & $\begin{array}{l}292 *(14) \\
311 *(15)\end{array}$ & $\begin{array}{l}180^{*}(21) \\
126(6)\end{array}$ & $\begin{array}{l}267 \text { (2) } \\
606 *(2)\end{array}$ & $\begin{array}{l}224^{*}(60) \\
206^{*}(33)\end{array}$ \\
\hline Diseases of the blood and blood forming organs $(280-289)$ & $\left\{\begin{array}{l}\mathbf{M} \\
\mathbf{F}\end{array}\right.$ & $\begin{array}{l}210 \\
579 *(3)\end{array}$ & $\begin{array}{l}109 *(3) \\
330 *(3)\end{array}$ & $\begin{array}{ll}213 & (4) \\
210 & (2)\end{array}$ & & $\begin{array}{l}160 *(10) \\
383 *(12)\end{array}$ \\
\hline Mental disorders (290-315) & $\left\{\begin{array}{l}\mathbf{M} \\
\mathbf{F}\end{array}\right.$ & $254^{*}(7)$ & 78 (1) & $\begin{array}{l}28 \text { (1) } \\
81 \text { (1) }\end{array}$ & & $\begin{array}{r}112(9) \\
26 \quad(1)\end{array}$ \\
\hline Diseases of the circulatory system $(390-458)$ & $\left\{\begin{array}{l}\mathrm{M} \\
\mathrm{F}\end{array}\right.$ & $\begin{array}{l}120 *(445) \\
107(113)\end{array}$ & $\begin{array}{l}115^{*}(260) \\
120^{*}(111)\end{array}$ & $\begin{array}{l}122 *(551) \\
125^{*}(88)\end{array}$ & $\begin{aligned} 133 & (38) \\
75 & (4)\end{aligned}$ & $\begin{array}{l}120^{*}(1341) \\
117^{*}(326)\end{array}$ \\
\hline Diseases of the respiratory system $(460-519)$ & $\left\{\begin{array}{l}\mathrm{M} \\
\mathrm{F}\end{array}\right.$ & $\begin{array}{l}109(80) \\
157 *(40)\end{array}$ & $\begin{array}{l}111(49) \\
112(24)\end{array}$ & $\begin{aligned} 104 & (86) \\
97 & (19)\end{aligned}$ & $\begin{array}{ll}40 & (2) \\
70 & (1)\end{array}$ & $\begin{array}{l}103 \cdot(220) \\
124^{*}(86)\end{array}$ \\
\hline Diseases of the digestive system $(520-577)$ & $\left\{\begin{array}{l}\mathbf{M} \\
\mathbf{F}\end{array}\right.$ & $\begin{array}{l}161 *(35) \\
108(11)\end{array}$ & $\begin{array}{l}143(18) \\
107(9)\end{array}$ & $\begin{array}{l}129(37) \\
171 \quad(13)\end{array}$ & $\begin{array}{r}56 \\
175 \text { (1) }\end{array}$ & $\begin{array}{l}143 *(96) \\
124 \quad(34)\end{array}$ \\
\hline Diseases of the genitourinary system $(580-629)$ & $\left\{\begin{array}{l}\mathbf{M} \\
\mathbf{F}\end{array}\right.$ & $\begin{array}{l}136 \\
328^{*}(12)\end{array}$ & $\begin{array}{l}199 *(10) \\
339^{*}(15)\end{array}$ & $\begin{array}{l}180 *(20) \\
257^{*}(11)\end{array}$ & 141 (1) & $\begin{array}{l}165^{*}(44) \\
278^{*}(44)\end{array}$ \\
\hline Accidents, poisoning, and violence (E800-999) & $\left\{\begin{array}{l}\mathbf{M} \\
\mathbf{F}\end{array}\right.$ & $\begin{array}{ll}115 & (97) \\
132 & (43)\end{array}$ & $\begin{array}{r}92(35) \\
112 \quad(25)\end{array}$ & $\begin{array}{l}78^{*}(99) \\
77(25)\end{array}$ & $\begin{array}{l}180^{*}(11) \\
142(3)\end{array}$ & $\begin{aligned} 95 & (251) \\
106 & (97)\end{aligned}$ \\
\hline
\end{tabular}

$* 0<05$. 
TABLE III-Proportional mortality ratios (numbers of deaths) for selected diseases by ethric group. (Bengalis and others not listed owing to small numbers)

\begin{tabular}{|c|c|c|c|c|c|c|}
\hline \multirow[b]{2}{*}{ Cause of death (ICD code) } & \multirow[b]{2}{*}{ Sex } & \multicolumn{4}{|c|}{ Ethnic groups } & \multirow{2}{*}{ Total } \\
\hline & & Punjabis & Gujaratis & Moslems & Southerners & \\
\hline Tuberculosis (010-019) & $\left\{\begin{array}{l}\mathbf{M} \\
\mathbf{F}\end{array}\right.$ & $\begin{array}{r}719 *(21) \\
1417 *(17)\end{array}$ & $\begin{array}{r}714^{*}(12) \\
1579 *(15)\end{array}$ & $\begin{array}{r}529 *(20) \\
1429 *(13)\end{array}$ & 417 (1) & $\begin{array}{r}607 *(54) \\
1442 *(45)\end{array}$ \\
\hline Diabetes mellitus (250) & $\left\{\begin{array}{l}\mathbf{M} \\
\mathbf{F}\end{array}\right.$ & $\begin{array}{l}314^{*}(19) \\
260^{*}(9)\end{array}$ & $\begin{array}{l}317^{*}(11) \\
417^{*}(12)\end{array}$ & $\begin{array}{l}220^{*}(17) \\
198(5)\end{array}$ & $\begin{array}{r}204 \\
1111 *(1)\end{array}$ & $\begin{array}{l}262 *(48) \\
303 *(28)\end{array}$ \\
\hline Chronic bronchitis (491) & $\left\{\begin{array}{l}\mathbf{M} \\
\mathbf{F}\end{array}\right.$ & $\begin{array}{l}58^{*}(17) \\
57 \text { (3) }\end{array}$ & $\begin{array}{l}37^{*}(6) \\
22\end{array}$ & $\begin{array}{ll}72 & (22) \\
30 & (1)\end{array}$ & 53 (1) & $\begin{array}{l}57^{*}(47) \\
44^{*}(6)\end{array}$ \\
\hline Cirrhosis of liver (571) & $\left\{\begin{array}{l}\mathrm{M} \\
\mathrm{F}\end{array}\right.$ & $\begin{array}{l}282 *(16) \\
108(3)\end{array}$ & $\begin{array}{c}213^{*}(7) \\
85(2)\end{array}$ & $\begin{aligned} 161 & (13) \\
98 & (2)\end{aligned}$ & & $\begin{array}{c}204 *(37) \\
94(7)\end{array}$ \\
\hline Suicide and self inflicted injury (E950-954) & $\left\{\begin{array}{l}M \\
F\end{array}\right.$ & $\begin{array}{l}121 \\
148 \quad(24)\end{array}$ & $\begin{array}{c}31^{*}(3) \\
151 \text { (10) }\end{array}$ & $\begin{array}{l}38 *(11) \\
47(4)\end{array}$ & $\begin{array}{ll}230 & (4) \\
152 & (1)\end{array}$ & $\begin{array}{c}69 *(43) \\
116 \quad(30)\end{array}$ \\
\hline Myocardial infarction (410-414) & $\left\{\begin{array}{l}\mathbf{M} \\
\mathbf{F}\end{array}\right.$ & $\begin{array}{ll}108 & (285) \\
117 & (57)\end{array}$ & $\begin{array}{l}121^{*}(196) \\
106(46)\end{array}$ & $\begin{array}{l}128^{*}(421) \\
128(40)\end{array}$ & $\begin{array}{ll}120 & (25) \\
126 & (3)\end{array}$ & $\begin{array}{l}121^{*}(968) \\
118^{*}(151)\end{array}$ \\
\hline Cerebrovascular disease $(430-438)$ & $\left\{\begin{array}{l}\mathrm{M} \\
\mathrm{F}\end{array}\right.$ & $\begin{array}{l}201 *(106) \\
101(30)\end{array}$ & $\begin{array}{ll}95 & (30) \\
90 & (23)\end{array}$ & $\begin{array}{l}112(67) \\
128(26)\end{array}$ & $134(5)$ & $\begin{array}{l}132 *(202) \\
100(79)\end{array}$ \\
\hline
\end{tabular}

$\cdot \mathrm{p}<0.05$.

TABLE IV-Proportional mortality ratios (number of deaths) for malignant neoplasms of selected sites by ethnic group. (Southerners, Bengalis, and others not included owing to small numbers)

\begin{tabular}{|c|c|c|c|c|c|}
\hline \multirow[b]{2}{*}{ Cause of death (ICD code) } & \multirow[b]{2}{*}{ Sex } & \multicolumn{3}{|c|}{ Ethnic groups } & \multirow{2}{*}{ Total } \\
\hline & & Punjabis & Gujaratis & Moslems & \\
\hline Buccal cavity or pharynx $(140-149)$ & $\left\{\begin{array}{l}M \\
F\end{array}\right.$ & $\begin{array}{l}127(4) \\
163 \quad(2)\end{array}$ & $\begin{array}{l}205 \text { (4) } \\
392 *(4)\end{array}$ & $\begin{aligned} 73 & (3) \\
235 & (2)\end{aligned}$ & $\begin{array}{l}133(13) \\
253 *(8)\end{array}$ \\
\hline Oesophagus (150) & $\left\{\begin{array}{l}\mathrm{M} \\
\mathrm{F}\end{array}\right.$ & $52(1)$ & $\begin{array}{ll}105 & (4) \\
226 & (4)\end{array}$ & $\begin{array}{r}53(4) \\
310 *(4)\end{array}$ & $\begin{array}{c}54^{*}(10) \\
173(9)\end{array}$ \\
\hline Stomach (151) & $\left\{\begin{array}{l}\mathrm{M} \\
\mathrm{F}\end{array}\right.$ & $\begin{array}{r}5^{*}(1) \\
18 \text { (1) }\end{array}$ & $\begin{array}{ll}50 & (6) \\
62 & (3)\end{array}$ & $40 *(9)$ & $\begin{array}{l}30^{*}(17) \\
28^{*}(4)\end{array}$ \\
\hline Large intestine, rectum, or rectosigmoid junction (153-154) & $\left\{\begin{array}{l}\mathrm{M} \\
\mathrm{F}\end{array}\right.$ & $\begin{array}{r}37^{*}(8) \\
8^{*}(1)\end{array}$ & $\begin{array}{l}84(11) \\
18^{*}(2)\end{array}$ & $\begin{array}{l}22^{*}(6) \\
25^{*}(2)\end{array}$ & $\begin{array}{l}38 *(25) \\
19 *(6)\end{array}$ \\
\hline Pancreas (157) & $\left\{\begin{array}{l}\mathrm{M} \\
\mathrm{F}\end{array}\right.$ & $\begin{array}{c}11^{*}(1) \\
136(5)\end{array}$ & $\begin{array}{ll}36 & (2) \\
30 & (1)\end{array}$ & $\begin{array}{r}37^{*}(4) \\
123(3)\end{array}$ & $\begin{array}{r}38^{*}(10) \\
102(10)\end{array}$ \\
\hline Trachea, bronchus, or lung (162) & $\left\{\begin{array}{l}\mathrm{M} \\
\mathrm{F}\end{array}\right.$ & $\begin{array}{l}24^{*}(19) \\
20^{*}(3)\end{array}$ & $\begin{array}{r}18^{*}(9) \\
8^{*}(1)\end{array}$ & $\begin{array}{l}41^{*}(39) \\
42(4)\end{array}$ & $\begin{array}{l}29 *(69) \\
21^{*}(8)\end{array}$ \\
\hline $\begin{array}{l}\text { Breast }(174) \\
\text { Cervix uteri }(180) \\
\text { Prostate }(185) \\
\text { Testis }(186)\end{array}$ & $\begin{array}{l}\mathrm{F} \\
\mathrm{M} \\
\mathrm{M}\end{array}$ & $\begin{array}{ll}15^{*}(5) \\
59 \\
34 \quad(2)\end{array}$ & $\begin{array}{l}43^{*}(12) \\
25^{*}(3) \\
54(2)\end{array}$ & $\begin{array}{l}85(19) \\
19 *(2) \\
18(1) \\
127(5)\end{array}$ & $\begin{array}{l}42 *(36) \\
34 *(13) \\
31 *(5) \\
60(5)\end{array}$ \\
\hline
\end{tabular}

* $\mathrm{p}<0.05$.

proportional mortality ratios of 282,201 , and 254 respectively. Deaths due to ischaemic heart disease were not significantly increased in Punjabis as opposed to other groups, and Punjabis also had the lowest mortality ratios for cancer overall in both sexes. Their lung cancer ratios, however, although nearly half that of Moslems, were not as low as in the Gujaratis. They also had low proportional mortality ratios for breast and gastrointestinal cancers. Gujaratis, from the state of Gujarat on the western border, are essentially traders and are Hindus or Jains by religion. Deaths due to diabetes were highest among them as were deaths due to neoplasms of the buccal cavity and pharynx. The ratio for lung cancer was lowest among the Gujaratis. Southerners formed a small group in England and Wales, with only 90 deaths during the study. Diseases of the circulatory system were highest in this group, although not significant. This was consistent with myocardial infarction being reported to be commonest in southern India. ${ }^{14}$ Significantly more deaths due to accidents, poisoning, and violence were found in this group.

Moslems were studied as a group as they have at least one distinctive characteristic: they are generally not vegetarians. They exhibited the highest proportional mortality ratios for cancer compared with the other groups, most appreciably for cancer of the lung or breast. Mortality due to cervical cancer was lowest in Moslem women, which could be related to the higher incidence of circumcision in the males. Moslems also had the highest ratios for ischaemic heart disease. All other groups had too few deaths to permit any comment.

We believe that the high and low values of proportional mortality ratios obtained in this study point to the existence of real variation between the ethnic groups in view of the internal consistency of the results and the supporting evidence from other studies. Particularly interesting are the differences in mortality due to cancer between the Hindus and the Moslems. The difference in risk between people born in England and Wales and migrants from the Indian subcontinent present an unrivalled opportunity for epidemiological studies to uncover the reasons for such difference to the benefit of migrants and natives alike. Surveys into eating habits, alcohol intake, and smoking patterns and determination of other cardiovascular risk factors are among some of the obvious possibilities.

We thank Martin Harman, community medicine, Southampton, for his computing help; Ruth Carleschi and staff, medical statistics division, Office of Population Censuses and Surveys, for help with calculations; and Anne Aykiran for typing the manuscript.

\section{References}

1 Pedoe HTT, Clayton D, Morris JN, Brigden W, McDonald L. Coronary heart attacks in east London. Lancet 1975;ii:833-8.

2 Walker ARP. The epidemiology of ischaemic heart disease in the different ethnic populans in Johanniolo. $S$ Afr Med $1980 ; 57 \cdot 748-52$.

. 7 Aust 1973;2:764-7.

4 Adelstein AM. Current vital statistics: methods and interpretation. $\mathrm{Br}$ Med $\mathcal{F}$

Cruickshank JK, Beevers DG, Osbourne VL, Haynes RA, Corlett JCR, Selby S. Heart attack, stroke, diabetes, and hypertension in West Indians, Asians, and whites in Birmingham, England. Br Med $\mathcal{F} 1980 ; 281: 1108$.
Marmot MG, Adelstein AM, Bulusu L. Immigrant motality in England and
Wales, 1970-78. London: HMSO, 1984. (Studies on Medical and Populations Wales, 1970-78. London: HMSO, 1984. (Studies on Medical and Populations
Subjects, No 47.)

7 World Health Organisation. International classification of diseases. 8th revision, 1965. Geneva: WHO, 1967.

8 Roman E, Beral V, Inskip H, McDowall M, Adelstein AM. A comparison of standardised and proportional mortality ratios. Statistics in Medicine $1984 ; 3$ :

9 Chopra S, Templeton AC. Cancer in east African Indians. Int 7 Cancer 1971;8:

10 Paymaster JC. Cancer and its distribution in India. Cancer 1964;17:1026-34.

11 Schonland $M$, Bradshaw $E$. Cancer in the Natal Africans and Indians, 1964-66. Int 7 Cancer 1968;3:304-16.

12 Bombay Cancer Registry. Cancer incidence in five continents. Vol 4 . Lyons: International Agency for Research in Cancer, 1982. (IARC Scientific Publications No 42 .

13 Malhotra SL. Geographical distribution of gastrointestinal cancers in India with

14 Malhotra SL. Epidemiology of ischaemic heart disease in India with special reference to causation. Br Heart $\mathcal{f} 1967 ; 29: 895-905$.

(Accepted 17 August 1984) 